\title{
The nascent ecology of social enterprise
}

\author{
Helen Haugh (i) • Paul Robson • John Hagedoorn • \\ Kate Sugar
}

\begin{abstract}
Employing population ecology theory, we examine social enterprise population emergence in the UK after 2005 when a new organizational form for social enterprise was established. Our density dependence analysis of nearly seven thousand community interest companies finds that survival is positively influenced by age and population densities of both other social enterprises and commercial organizations. Two specific patterns in population emergence are identified: social enterprise survival is more likely influenced by industry than age, a finding that we label the liability of specificity, and their survival benefits from the population density of commercial organizations but not nonprofit organizations, a finding that we label the hybrid-
\end{abstract}

H. Haugh $(\bowtie)$

Judge Business School, University of Cambridge, Trumpington Street, Cambridge CB2 1AG, UK

e-mail: h.haugh@jbs.cam.ac.uk

P. Robson · J. Hagedoorn

School of Management, Royal Holloway University of London, Egham TW20 0EX, UK

P. Robson

e-mail: Paul.Robson@rhul.ac.uk

J. Hagedoorn

e-mail: John.Hagedoorn@rhul.ac.uk

\section{K. Sugar}

Maternity Career Break, Formerly School of Management, University of Bath, Claverton Down, Bath BA2 7AY, UK

e-mail: katethirlaway@googlemail.com commercial benefit. Our research identifies the liability of specificity as a new concept in population ecology theory and the hybrid-commercial benefit as a contextual influence on social enterprise survival.

Keywords Population ecology · Density dependence . Social enterprise $\cdot$ Survival $\cdot$ Community interest companies

JEL $\mathrm{L} 26 \cdot \mathrm{L} 31 \cdot \mathrm{M} 21 \cdot \mathrm{P} 31$

\section{Introduction}

Scholarly interest in social enterprise (SE) is growing rapidly (Lepoutre et al. 2013). In the UK, the community interest company (CIC), a legally constituted organizational form for SE, was established in 2005 to overcome the institutional ambiguity associated with organizations that pursue both commercial and social goals. New organizational forms foster economic diversity (Romanelli 1989), yet the emergence of new entrepreneurial populations is relatively neglected in entrepreneurship research (Liu and van Witteloostuijn 2020). While prior SE research has examined different levels of analysis, such as international (Lepoutre et al. 2013), county (Andersson and Ford 2016; Chang et al. 2011), and city level (Barron et al. 1994; Bouchard and Rousselière 2016), the main focus of our study of CICs is to improve the understanding of the national contextual and institutional influences on SE population emergence. Our research responds to the question: Which 
factors determine SE survival during SE population emergence?

The rationale for investigating the determinants of SE survival lies in the confluence of two trends. First, for some time, it was considered that the survival of organizations that bridged different domains was rare (Zuckerman 1999), yet hybridity is a defining characteristic of the increasing population of SEs (Brandsen et al. 2005), and in at least one industry, nanotechnology, hybridity has been leveraged to access resources (Wry et al. 2014). Second, while macro level analyses of SEs are increasing, they all face the challenge of precise sample specification (Andersson and Ford 2016; Barron et al. 1994; Bouchard and Rousselière 2016; Chang et al. 2011; Estrin et al. 2013; MendozaAbarca et al. 2015). The UK CIC legislation established a new legal form for SE that removed prior ambiguity concerning SE definition and, as a CIC must be formally registered as such, created an opportunity to investigate SE population emergence.

In line with entrepreneurship research in general, that has been dominated by individual and organizational levels of analysis (Davidsson and Wiklund 2001), the broad trends in SE have, until recently, been overlooked (Kerlin 2017). Yet examining the patterns of SE founding and survival is important for understanding entrepreneurial population variation (Aldrich 1990). Population ecology theory examines contextual influences on the emergence of new organizational forms where the unit of analysis is found at the population level (Andersson and Ford 2016; Bogaert et al. 2016; Hannan and Freeman 1989; Núñez-Nickel and Moyano-Fuentes 2006). An organizational population is defined as a group of organizations that share a set of common characteristics such as structure, practices, members, routines, and competition for similar resources (Baron 2004; Hannan and Freeman 1977, 1989). Our study examines the intra- and interpopulation influences on SE survival by comparing SE population densities over time and against both commercial and non-profit organizations. By doing so, we respond to calls for further research to investigate contextual and inter-population influences on SE survival (Kerlin 2017).

We employ population ecology theory to generate five hypotheses that predict the relationships between SE survival and population density, age, strategy, and the population densities of commercial and non-profit organizations. Our data supports the liability of newness
(Stinchcombe 1965) in that the cumulative knowledge, skills, and networks of older SEs explain why they are more likely to survive than younger SEs. In addition, generalist SEs are more likely to survive than specialists, thus partially supporting market positioning theories (Brittain and Freeman 1980; Lambkin and Day 1989). Further, SE survival is enhanced by the population densities of commercial, but not non-profit, organizations.

Our study makes two contributions. First, our investigation of SE population emergence departs from previous single industry studies (Audia et al. 2006; Barnett and Carroll 1987; Boone and Öscan 2014) by examining the population dynamics across a range of industries. In doing so, our results suggest that SE survival varies by industry and strategic focus - an effect we label a liability of specificity. Second, our investigation of SE population emergence finds a positive relationship between SE survival and commercial organization density. We label this effect the hybrid-commercial benefit.

The article is structured as follows: we first review the literatures on SE and organizational ecology and then develop hypotheses to predict SE survival. The methodology and operationalization of the variables are followed by the empirical results and discussion. The paper concludes with contributions to population ecology theory and social entrepreneurship and implications for practitioners.

\section{Background and hypotheses}

\subsection{Social enterprise}

SEs pursue financial sustainability at the same time as generating social and environmental impacts, such as to reduce social exclusion, enhance employment opportunities, and protect the environment (Lepoutre et al. 2013; Zahra et al. 2009). SEs are distinguished from charities and other non-profit organizations by generating a proportion of income from trading (Di Domenico et al. 2010). For example, the UK baseline is set at generating more than $25 \%$ of income from trading (DTI 2002). In 2005 a new law was passed in the UK which brought together, for the first time, both commercial activity and social mission into one organizational form - the CIC. The CIC is a special type of limited liability company, ineligible for tax exemptions extended to non-profit organizational forms, in which activities 
benefit a community of interest rather than shareholders. The CIC organizational form was designed to enable the simultaneous pursuit of commercial and social missions and preserve, through an asset lock, the commitment of assets to social mission in perpetuity. A CIC may be registered as limited either by guarantee or shares, and CIC trustees can elect to be paid for governance activities. The registration of a CIC comprises, first, registration as a company subject to approval by Companies House and, second, registration as a CIC subject to approval by the CIC Regulator. In addition to the submission of annual financial statements to Companies House, a CIC is required to submit an annual CIC statement in which the benefits to the specified community of interest are presented (DBEIS 2016). The hybrid nature of the CIC rests in the combination of characteristics from commercial and non-profit organizational forms.

Institutional change, such as initiated by political events, are known to precipitate conditions for the emergence of new organizational forms (Brittain 1994; Carroll et al. 1988; Minkoff 2002; Romanelli 1989), and the legislation to establish the CIC organizational form ensures that founders do not face making a choice between profits and social mission (Battilana et al. 2012). Trading is broadly defined as the market-based exchange of goods and services, e.g. service delivery contracts, and is distinguished from grants and donations which are received without the need for commercial exchange. The community interest requirement is that at the point of registration, the CIC must declare commitment to serving a community (directly or indirectly) that is wider than its organizational membership.

\subsection{Social enterprise density dependence}

To empirically examine SE survival during population emergence, we employ population ecology theory which proposes that organization founding rates and survival are determined by the legitimacy gained from the increasing density of similar organizations and the availability of resources for which organizations compete (Aldrich 1990). Legitimacy and resources are fundamental to organizational survival (Suchman 1995; Aldrich and Fiol 1994), and the confounding effect of these two variables produces a pattern in which the rate of population density increases and then levels off (Aldrich 1990; Hannan and Freeman 1977). This pattern of organization founding rates has been found in a range of industries (see Lomi et al. 2010 for a review), voluntary organizations (Tucker et al. 1990), labour unions (Hannan and Carroll 1992), trade associations (Aldrich et al. 1994), and cooperatives (Ingram and Simons 2000).

Specific to hybrid organizations, such as SEs, the emergence and growth of voluntary organizations that combine political advocacy and service provision is found to positively influence the viability of similar hybrid organizations (Minkoff 2002). The UK is widely recognized as a country wherein the institutionalization of policies to promote and advance SE has progressed further and faster than anywhere else in the world (Nicholls 2010).

Following population ecology theory, we expect that during population emergence, SE founding rates will increase (Hannan et al. 1995; Sorenson and Audia 2000). This is because the legitimizing effect of the supportive policy and legislative environment increases the probability that social entrepreneurs will adopt the new CIC form. Although the increase in population density puts pressure on the availability of resources (Hannan and Freeman 1987), supportive policies to legitimize the CIC form (DTI 2002) increase regulative, normative, and cognitive legitimacy, and thus the attractiveness of adopting the CIC form which leads to a net SE increases in both founding and survival.

\subsubsection{Hla.As the population density of SE increases, the likelihood of SE founding and survival increases}

\subsection{Social enterprise age and survival}

Previous studies of organizational survival have consistently found that younger organizations are less likely to survive than older organizations (Carroll 1984; Hager et al. 2004; Hannan and Freeman 1977). Organizational mortality declines with age (Barnett and Carroll 1987), and the effects of age persist even when controlling for organization size, time, and population heterogeneity (Freeman et al. 1983). The liability of newness (Stinchcombe 1965) explains that this pattern is because young organizations suffer from lack of business skills, experience, market knowledge, poor entrepreneur networks (Aldrich 1990), and lack of knowledge of new organizational forms (Ruef 2000). These variables impact negatively on organization survival. To help young organizations overcome the liability of newness and prosper, government policies channel resources to 
support entrepreneurs and young organizations (Amezcua et al. 2013). In contrast, older organizations are more likely to survive because they reap the benefits from the establishment of a loyal customer base, reputation, and supportive networks.

Organization survival is also influenced by legitimacy, and this is especially so for SE (Dacin et al. 2011). Regulative legitimacy, for example, as conferred by legislation, is a powerful institutional force (Tucker et al. 1990) which helps to bolster interactions between stakeholders (Dacin et al. 2010). The CIC form legislation specified the registration criteria and instituted a CIC Regulator to monitor and control adoption. Although the provision of support for new SEs (DTI 2002) and access to bespoke trade associations, e.g. the CIC Association and Social Enterprise UK (formally Social Enterprise Coalition), goes some way to helping young SEs access resources and networks, the skills, experience, and networks which founders of older SEs have invested in building up over time confer on them greater likelihood of survival.

\subsubsection{H1b.The older the SE, the greater the likelihood of survival}

\subsection{Social enterprise strategic focus and survival}

Population ecology theory also predicts that organization survival varies according to strategic focus (Brittain and Freeman 1980; Lambkin and Day 1989). In population emergence, first-mover advantages help organizations to acquire resources and establish specialist market niches. Later, as population density approaches carrying capacity, organizations that adopt strategies that serve broader, more generalist domains are more likely to survive (Brittain and Freeman 1980). For example, niche market firms are associated with greater experimentation (Raven 2007), which is in turn associated with higher risk of failure (Henderson 1999). When we consider that SEs operate in resource scarce environments (Kickul et al. 2013), those that serve specialist markets are also likely to require more specific factor inputs than those that serve broad markets (Baron 2004), thereby increasing competition for resources and the likelihood of failure.

In addition, during adverse economic times when the level of social need is high (Austin et al. 2006) and there are more stringent funding conditions (Mort et al. 2003), it is likely that SE survival will be associated with greater resource acquisition flexibility and strategies that appeal to a wider a range of constituencies. SEs that survive will do so because they make the most efficient use of available resources and appeal to wider markets. Although a specialist niche strategy would differentiate products and services between competitors and appeal to specialist sources of funds (Zahra et al. 2008), a broader generalist portfolio of activities facilitates the spreading of risk across different constituencies.

\subsubsection{H1c.Generalist SEs will be more likely to survive than specialist SES}

\subsection{Social enterprise survival and inter-population density}

Population ecology theory explains how organizational founding and survival is also dependent on the impact that one population of organizations has on another population (Aldrich 1990; Audia et al. 2006; Barnett and Carroll 1987; Freeman and Audia 2006). The relationship between organization populations may be symbiotic (Aldrich 1990; Audia et al. 2006; Estrin et al. 2013; Halliday et al. 1987), complementary (Aldrich 1990; Audia et al. 2006; Bielefeld and Murdoch 2004; Staber 1989), or competitive (Aldrich 1990; Hannan and Freeman 1987; Mendoza-Abarca et al. 2015). For example, the relationships between three Canadian cooperative organizational forms was found to be complementary (Staber 1989), whereas a competitive relationship was noted between commercial and tax-exempt social ventures (Mendoza-Abarca et al. 2015).

The SE organizational form bridges the boundaries between commercial and non-profit sectors (Bacq and Janssen 2011) since they do not solely subscribe to the set of characteristics of either commercial or non-profit organizations. For instance, commercial organizations generate income through trading and are primarily driven by the profit motive to create value for shareholders. In contrast, non-profit organizations derive income from government funding, philanthropy or private donations, and not trading. The defining characteristic of SEs is thus their hybridity: sharing regulatory characteristics from commercial company law, i.e. income from trading, limited liability, the issuance of share capital, and distribution of dividends to shareholders; and charity law, i.e. social and environmental mission and eligibility to receive government funding and private donations (Mendoza-Abarca et al. 2015; Zahra and Wright 2011). 
Prior research has explored the influence of complementary and competitive relationships between population densities in the commercial (Barnett 1990; Barnett and Carroll 1987; Halliday et al. 1987; Wade 1996) and non-profit sectors (Hannan and Freeman 1987) and between organizational forms, e.g. cooperatives and corporations (Boone and Öscan 2014; Ingram and Simons 2000; Simons and Ingram 2003). As SEs occupy an institutional space that falls between commercial and non-profit sectors (Billis 2010; Tracey et al. 2011), they share some characteristics from both organization populations (King et al. 2011). To accommodate the hybridity arising from mixing elements from different organization categories (Wry et al. 2014), we investigate inter-population determinants of SE survival by comparing population densities of SEs with commercial and non-profit organizations.

The market failure hypothesis predicts that SEs serve markets that have been deemed unviable by commercial organizations (Billis 2010; Katz and Page 2010) and thus suggests a negative relationship between the population densities of SEs and commercial organizations. Three prior studies find a negative relationship between $\mathrm{SE}$ and commercial venture creation (Abarca and Anokhin 2012; Mendoza-Arbaca et al. 2015; Kachlami 2017). However, although these prior studies refer to social ventures, the SE organizational forms analysed are tax exempt and thus non-profit organizational forms. In contrast, the CIC organizational form is a company and ineligible for tax exemptions. From a resource perspective, even if insufficient for full commercial exploitation, the presence of some commercial viability may reflect a supportive infrastructure, such as established transportation, communication, supply networks, and business support and a pool of skilled labour, access to finance, reduced customer search costs, knowledge spill overs, and technological support (Baum and Haveman 1997). In addition, as explained by Roundy (2017), such a supportive infrastructure benefits from existing commercial organizations that create an environment that enables managerial capabilities development within SEs through learning from more conventional entrepreneurs. Such a supportive infrastructure and resource pool will reduce costs and foster SE survival (Bielefeld and Murdoch 2004; Marquis et al. 2013; Roundy 2017). Moreover, the resource needs of SEs differ from commercial ventures (Dees and Anderson 2003), and thus the relationship between SE survival and the population density of commercial organizations may thus be symbiotic (Estrin et al. 2013). We therefore predict that SE survival benefits from the population density of commercial organizations.

\subsubsection{H2a.The higher the population density of commercial organizations, the higher the likelihood of SE survival}

Turning to SE survival and the density of non-profit organizations, the relationship is affected by the crowding of organizations in the same resource niche (Bosma et al. 2011). There are two factors to consider. First, although the generation of trading income distinguishes SEs legally from charities, few SEs rely solely on trading income (Cooney 2011; Katz and Page 2010). Many charities also engage in mission-related income generation with the proviso that any profits are used to advance the charitable mission and not distributed as perquisites (Katz and Page 2010). However, the economic downturn (Smiddy 2010) and government retrenchment have reduced funding for non-profit organizations (Cooney 2011; Salamon 1999), especially hybrid organizations (Cooney 2006). Thus, SEs are likely to compete with non-profit organizations for grants, donations, and programme-related investments. Second, both SEs and non-profit organizations serve the disadvantaged and socially excluded and thus may also compete for service users. Although collaboration between SEs and charities could increase the supply of services to those in need (Smiddy 2010), they compete with each other for resources and beneficiaries. The more similar the resource needs and markets served, the greater the competition between the organizational forms (Baum and Haveman 1997). Hence, the population density of registered non-profit organizations will thus have a detrimental effect on SE survival.

\subsubsection{H2b.The higher the population density of registered non-profit organizations, the lower the likelihood of SE survival}

\section{Methodology}

\subsection{Data collection}

To test the hypotheses, we assembled multiple large data sets. The population of SEs was derived from the register of CICs in the UK between 2005 and 2012. The CIC 
register lists every SE that has satisfied the registration requirements stipulated by the CIC Registrar. The register lists the CIC date of registration, date of dissolution (if relevant), postal address, and standard industry classification (SIC) code. Emerging populations are difficult to study because it is hard to specify when they transition from emergence to growth or maturity. Following population ecology theory (Aldrich 1990), we marked the end of the population emergence period as when the rate of increase in CIC registration levelled off.

The population constitutes 6868 registered CICs and using each year of registration per CIC as a data spell generated a total of 21,607 CIC-year spells. The Office for National Statistics (ONS) (ONS 2004-2012) provides the number of commercial organizations established per year. Geoconvert at the UK Data Service Census Support (Geoconvert 2004) lists the location classification of commercial organizations by postcode (zip code). The register of charities prepared by the National Council of Voluntary Organizations (NCVO) lists the postcode for charities in England, Wales, and Northern Ireland (NCVO 2004-2012) and the Annual Population Survey measures of population density (ONS 2004-2012). ONS also provide gross value added (ONS 2004-2012) which measures the value of goods and services produced in an industry, area, or economic sector.

\subsection{Dependent variable}

The principal focus of the analysis is to examine SE survival during population emergence by investigating the rate of CIC founding and dissolution. An important issue in population ecology research is pinpointing exactly when birth and exit of an organization have occurred (Delacroix and Carroll 1983). We define a CIC birth as the date of incorporation and exit as the date of dissolution - both dates recorded by the CIC Regulator. Organizational exit, an established measure in population ecology research (Amburgey et al. 1993; RangerMoore 1997; Ingram and Simons 2000; Minkoff 2002), is relevant for populations of young ventures (Amezcua et al. 2013) and has the advantage of being unambiguous to determine (Barnett and Carroll 1987). Our dissolution measure corresponds to delisting from an industry directory (Barnett 1990; Sorenson and Audia 2000). We investigate the hazard variable of CIC dissolutions between July 2005 and December 2012. The timeframe captures the total population of CICs in the UK and compares well with studies that explore the emergence of new organizational forms, e.g. 8 years (Persson 2004) and 10 years (Baum and Oliver 1992), and interpopulation densities, e.g. 5 years (Mendoza-Abarca et al. 2015). Further, understanding population emergence is important 'because the struggle to carve out a niche involves such strong forces' (Aldrich and Ruef 2006, p. 205) and the dissolution hazard increases in the first few years after formation (Nucci 1999).

\subsection{Independent variables}

Measures for the independent variables to test the hypotheses are generated from merging the data sets. The population density of SE is measured by the total number of CICs for each event year (National CIC). This corresponds to the density measure adopted in population ecology studies (Boone and Öscan 2014; Minkoff 2002; Ingram and Simons 2000; Simons and Ingram 2003). SE age (Age CIC) is measured by the number of months after registration that the CIC remains on the register for each of the event years (Ingram and Simons 2000; Minkoff 2002). Whether an SE is a generalist or specialist is derived from the CIC activity indicated by Standard Industrial Classification (SIC) code and used to produce a series of dummy variables (Audia et al. 2006; Ingram and Simons 2000; Ruef and Patterson 2009). The UK SIC classifies organizations according to the type of economic activity in which they are engaged (ONS 2012). We label wholesale and retail as a 'generalist' sectoral activity to contrast with the other thirteen groups of sectors which we consider to be more 'specialist'. The rationale for labelling wholesalers and retailers as generalist is because they provide distribution services to make a wide range of products and services available to buyers and customers (Watson et al. 2015). Wholesalers and retailers thus succeed by being general exchange facilitators rather than product specialists (OXRIM 2014; see also https:/www. business.gov.au/planning/templates-and-tools/industryfactsheets/retail-and-wholesale-trade-industry-factsheets). In addition real estate, the primary asset of traditional wholesalers and retailers, is readily deployable across industries and can be transferred to alternative uses without sacrificing productive value (Williamson 1995). The population density of commercial organizations was derived from data indicating the establishment of new small and medium-sized enterprises (SMEs) (ONS 2004-2012). SE surveys have 
consistently found low turnover in young SEs ( $£ 30,000$, up to 3 years; $£ 80,000$, between 3 and 5 years; and $£ 150$ ,000, 6 to 10 years) (Social Enterprise UK 2017). As these average turnovers categorize most SEs as small businesses (OECD 2014), we compared CIC with SME populations. The population density of non-profit organizations uses registered charities (NCVO 2004-2012). This method is in line with established use of lists by organizational form and industry registers in population ecology research (Barnett 1990; Barnett and Carroll 1987; Boone and Öscan 2014; Ingram and Simons 2000; Lomi 1995; Minkoff 2002; Simons and Ingram 2003).

\subsection{Control variables}

We include control variables to account for alternative explanations of founding, survival, and carrying capacity. We controlled for location since geographic space heterogeneity influences venture founding and survival (Barnett 1990; Chang et al. 2011; Lomi 1995; Ingram and Simons 2000; Simons and Ingram 2003; Teasdale 2010). Although the higher concentration of people and organizations in urban areas implies greater resource availability and markets, organizations in rural areas gain from greater local embeddedness (Bird and Wennberg 2014). The full address and postcode of each CIC were employed to allocate each CIC to one of eight geographical variables, which range from urban to rural. ${ }^{1}$ We also controlled for area wealth as economic conditions also affect venture founding and survival (Chang et al. 2011; Ingram and Simons 2000; Mendoza-Abarca et al. 2015). The level of wealth in a location is captured using gross value added (20042011). Finally, we controlled for demography as population impacts directly on organization founding and

\footnotetext{
${ }^{1}$ Urban settlements with a population of 10,000 or more and the wider surrounding area are sparsely populated (urban $\geq 10 \mathrm{k}$, sparse); small town and fringe areas where the wider surrounding area is sparsely populated (town and fringe, sparse); village and wider surrounding area which is sparsely populated (village, sparse); hamlet and isolated dwelling and the wider surrounding area which is sparsely populated (hamlet and isolated dwelling, sparse); urban settlements with a population of 10,000 or more and the wider surrounding area which are less sparsely populated (urban $\geq 10 \mathrm{k}$, less sparse); small town and fringe areas and the wider surrounding area which are less sparsely populated (town and fringe, less sparse); village and the wider surrounding area which is less sparsely populated (village, less sparse); finally, hamlet and isolated dwelling and the wider surrounding area which are less sparsely populated (hamlet and isolated dwelling, less sparse).
}

survival (Chang et al. 2011; Ruef and Patterson 2009). Table 1 provides a full description of the variables.

3.5 Data analysis, reliability, and robustness checks

Given the nature of our data, we apply multi-level regression models (Goldstein 2011; Singer and Willett 2003; Rabe-Hesketh and Skrondal 2012; StataCorp 2017a) that allow researchers to analyse data characterized by a multi-level structure while accounting for the clustering of lower level units within higher level units (Austin 2017). Our analysis employs multi-level mixed effects models using the release 15 version of Stata (StataCorp 2017a, b) and reports results of mixedeffects Weibull PH regression models for a series of 7 models. The likelihood-ratio test, reported for each of the 7 models, compares the random-effects model against the fixed-effects only. For all 7 models, the likelihood-ratio tests are highly statistically significant and support the use of the random-effects model.

The data set constitutes the population of registered CICs, and thus there is robust content and face validity. Analysis of the total organization population also minimizes response bias and measurement errors. Although the databases are extensive, they are not comprehensive; missing items were sourced by the research team; however, after thorough searches, we dropped $247 \mathrm{CICs}$ due to missing data. We performed a chi-square test and found no evidence of a statistically significant difference at the 0.05 level, or better, between the eliminated CICs and the remaining CICs by age or sector. Thus, we are confident that the results are reliable indicators of the determinants of SE survival during population emergence.

\section{Results}

\subsection{Descriptive statistics}

Between 2005 and 2012, 5729 CICs (of 6868 registrations) remain on the CIC register. The average number of surviving CICs is 3406 per year (National CIC), and the average age is 25.2 months (Age CIC). The percentage of CICs in different industries are public administration and defence, compulsory social security, and education (public sector) (22.1\%); real estate and professional, scientific, and technical activities (real estate) $(14.6 \%)$; human health and social work activities 
Table 1 Variable descriptions

\begin{tabular}{|c|c|c|c|}
\hline Variable & Definition & Mean & S.D. \\
\hline Dissolution CIC & CIC dissolution (2005-2012) & 0.054 & 0.424 \\
\hline Time & Time in months to dissolution or end of the experiment period & 43.437 & 20.975 \\
\hline CIC LAA & Population of CICs at the local authority area & 62.552 & 5.7111 \\
\hline Age CIC & Age of the CICs in months & 25.217 & 18.704 \\
\hline SIC $01-03$ & CICs with a SIC code 01 up to 03 (agriculture, forestry, and fishing) & 0.031 & 0.172 \\
\hline SIC $10-33$ & SIC code 10-33 (manufacturing) & 0.014 & 0.117 \\
\hline SIC $35-39$ & $\begin{array}{l}\text { SIC code 35-39 (electricity, gas, steam, and air conditioning supply; } \\
\text { water supply, sewerage, waste management, and remediation activities) }\end{array}$ & 0.007 & 0.085 \\
\hline SIC $41-43$ & SIC code $41-43$ (construction) & 0.005 & 0.068 \\
\hline SIC $45-47$ & SIC code $45-47$ (wholesale and retail trade) & 0.022 & 0.146 \\
\hline SIC $49-53$ & SIC code $49-53$ (transportation and storage) & 0.006 & 0.080 \\
\hline SIC 55-56 & SIC code $55-56$ (accommodation and food services) & 0.021 & 0.143 \\
\hline SIC 58-66 & SIC code 58-66 (information and communication; financial and insurance activities) & 0.062 & 0.242 \\
\hline SIC $68-75$ & $\begin{array}{l}\text { SIC code } 68-75 \text { (real estate activities; professional, } \\
\text { scientific and technical activities) }\end{array}$ & 0.146 & 0.352 \\
\hline SIC 77-82 & SIC code $77-82$ (administrative and support service activities) & 0.073 & 0.259 \\
\hline SIC $84-85$ & $\begin{array}{l}\text { SIC code } 84-85 \text { (public administration, compulsory } \\
\text { social security; education) }\end{array}$ & 0.221 & 0.416 \\
\hline SIC $86-88$ & SIC code $86-88$ (human health and social work activities) & 0.143 & 0.349 \\
\hline SIC 90-93 & SIC code $90-93$ (arts, entertainment, and recreation) & 0.137 & 0.344 \\
\hline SIC 94-99 & $\begin{array}{l}\text { SIC code 94-99 (other service activities; activities of households } \\
\text { as employers, undifferentiated goods- and services-producing } \\
\text { activities of households for own use; activities of extraterritorial } \\
\text { organizations and bodies) }\end{array}$ & 0.122 & 0.327 \\
\hline SME LAA & Population of SMEs in the local authority area (thousands) & 10.399 & 8.465 \\
\hline Charities LAA & Population of registered charities in the local authority area (tens) & 46.385 & 42.404 \\
\hline Urban $\geq 10 \mathrm{k}$-sparse & $\begin{array}{l}\text { Urban } \geq 10 \mathrm{k}-\text { sparse: urban settlements with a population of } 10,000 \\
\text { or more and the wider surrounding area is sparsely populated (2010) }\end{array}$ & 0.003 & 0.056 \\
\hline Town/Fringe - sparse & $\begin{array}{l}\text { Town and Fringe - sparse: small town and Fringe areas and the wider } \\
\text { surrounding area is sparsely populated (2010) }\end{array}$ & 0.007 & 0.085 \\
\hline Village - sparse & $\begin{array}{l}\text { Village - sparse: Village category and the wider surrounding area is } \\
\text { sparsely populated (2010) }\end{array}$ & 0.009 & 0.093 \\
\hline Isolated dwelling — sparse & $\begin{array}{l}\text { Hamlet and isolated dwelling — sparse: hamlet and isolated dwelling } \\
\text { and the wider surrounding area is sparsely populated (2010) }\end{array}$ & 0.005 & 0.068 \\
\hline Urban $\geq 10 \mathrm{k}$-less sparse & $\begin{array}{l}\text { Urban } \geq 10 \mathrm{k} \text { - less sparse: urban settlements with a population of } \\
10,000 \text { or more, and the wider surrounding area is } \\
\text { less sparsely populated (2010) }\end{array}$ & 0.814 & 0.389 \\
\hline Town/Fringe-less sparse & $\begin{array}{l}\text { Town and Fringe-less sparse: small town and fringe areas category } \\
\text { and the wider surrounding area are less sparsely populated (2010) }\end{array}$ & 0.069 & 0.253 \\
\hline Village_-less sparse & $\begin{array}{l}\text { Village_-less sparse: village category and the wider surrounding area } \\
\text { are less sparsely populated (2010) }\end{array}$ & 0.056 & 0.229 \\
\hline Isolated dwelling_-less sparse & $\begin{array}{l}\text { Hamlet and isolated dwelling-less sparse: hamlet and isolated dwelling } \\
\text { category and the wider surrounding area is less sparsely populated (2010) }\end{array}$ & 0.038 & 0.190 \\
\hline GVA LAA & Gross value added per head in the local authority area (in thousands) & 24.538 & 15.487 \\
\hline Human Pop LAA & The population in the local authority area (in thousands) & 432.781 & 381.942 \\
\hline
\end{tabular}

(human health) (14.2\%); and arts, entertainment, and recreation (arts and entertainment) (13.7\%). Taken together, these four industrial activities account for $64.6 \%$ of CICs. The next two groups of industrial activity accounted for $19.5 \%$ of CICs: other service activities, activities of households as employers (other service 
activities) (12.2\%) and administrative and support service activities (administrative) (0.073). Thus, cumulatively $84.1 \%$ of CICs operate in six groups of industrial activity, and the remaining $15.9 \%$ operate in eight groups of industrial activity.

In relation to geographical location, nearly $90 \%$ of the CICs are found in an urban and town setting. Thus, the adoption of CICs appears to be an urban phenomenon.

4.2 Social enterprise population density, age, strategy, and survival

Table 2 presents variable correlations and shows that for some variables, there are higher degrees of collinearity; hence, it was necessary to run some models without the full range of variables. Table 3 presents the CIC survival regressions from 2005 to 2012. Model 1 is the baseline with control variables, and models 2-6 add each hypothesised variable. In model 2 , the population density of CICs is added to the control variables. In model 3 , the control variables are augmented with CIC age. In model 4 , the CIC industry activity dummy variables are added to the control variables. In model 5, the number of SMEs is added to the control variables. In model 6 , the number of charities is added to the control variables. Model 7 reports the full model.

Hypothesis 1a predicted that the higher the population density of SEs, the higher the likelihood of SE founding and survival (Table 3). Models 2 and 7 have hazard ratios of less than one which indicate that as the population density of CICs increases, the lower the likelihood of CIC dissolution at the 0.001 level. In model 7 , the hazard ratio for the population density of SEs is 0.960 . The hazard ratio shows the change in the risk of dissolution if the parameter we are looking at rises by one unit. Thus, for a unit change in the population density of SEs, the risk of dissolution falls by $4 \%$. In support of hypothesis 1a, there is a positive statistically significant relationship between CIC population density and survival. The implication of this result is that the carrying capacity of the CIC population has yet to be reached.

Hypothesis $1 \mathrm{~b}$ predicted that the older the SE, the greater the likelihood of survival. In line with our predictions, in models 3 and 7, we find that older SEs are more likely to survive than younger SEs. Hence, the results support hypothesis $1 \mathrm{~b}$. In model 7 , the hazard ratio of the age of the SEs is 0.858 . Thus, for a unit change in the age of the SEs, the risk of dissolution falls by $14.2 \%$. Hypothesis $1 \mathrm{c}$ argued that generalist SEs will be more likely to survive than specialist SEs. The results in models 4 and 7 show that the specialist SIC categories of agriculture, forestry, and fishing (SIC 01-03), utilities (SIC 35-39), construction (SIC 41-43), and manufacturing (SIC 10-33) are less likely to survive compared to the wholesale and retail sector (SIC 4547). These results are statistically significant at the 0.001 level. Although some specialist CICs are significantly more likely to survive than generalists, for others our results do not indicate such a relationship. Therefore, there is partial evidence to support hypothesis $1 \mathrm{c}^{2}{ }^{2}$

\subsection{Social enterprise inter-population density and survival}

Hypothesis 2a predicted that that the higher the population density of commercial organizations, the higher the likelihood of SE survival. Results in models 5 and 7 find a statistically significant positive relationship between the population density of SMEs and SE survival. Thus, the results from models 5 and 7 support hypothesis $2 \mathrm{a}$. In model 7, the hazard ratio of the population density of commercial organizations is 0.969 which means that a unit change in the population density of commercial organizations, i.e. for every ten thousand commercial organizations at the local authority area, the risk of dissolution falls by $3.1 \%$. Hypothesis $2 \mathrm{~b}$ predicted that the higher the population density of non-profit organizations, the lower the likelihood of SE survival. The results in model 6 and model 7 support hypothesis $2 b$. Turning to model 7, we note that the hazard ratio of the population density of non-profit organizations is 1.042 , showing that there is a $4.2 \%$ greater risk of dissolution for a unit change in population density of non-profit organizations.

Turning attention to the control variables, we note that the higher the GVA, the level of wealth in a location, the higher the likelihood of SE survival and that the higher the population density of the human population, the higher the likelihood of SE survival. We note also that two of the location variables are statistically significant: CICs located in urban $\geq 10 \mathrm{k}$, sparse areas, and in town and fringe, sparse areas, are more likely to survive

\footnotetext{
${ }^{2}$ We also re-ran all of the models dropping three SEs whose activity falls within the repair of motor vehicles and motor cycles. The effect on the results was negligible.
} 

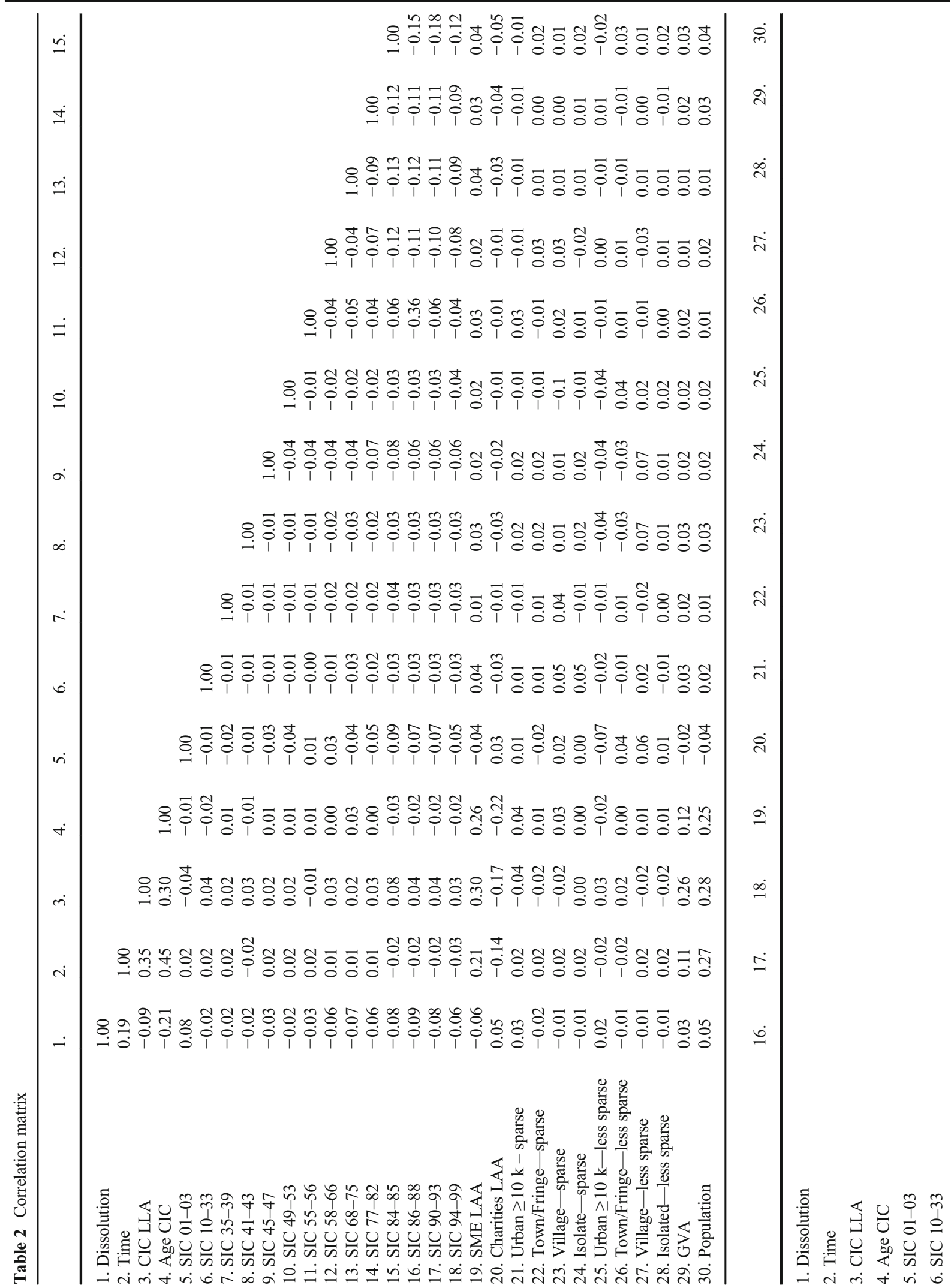


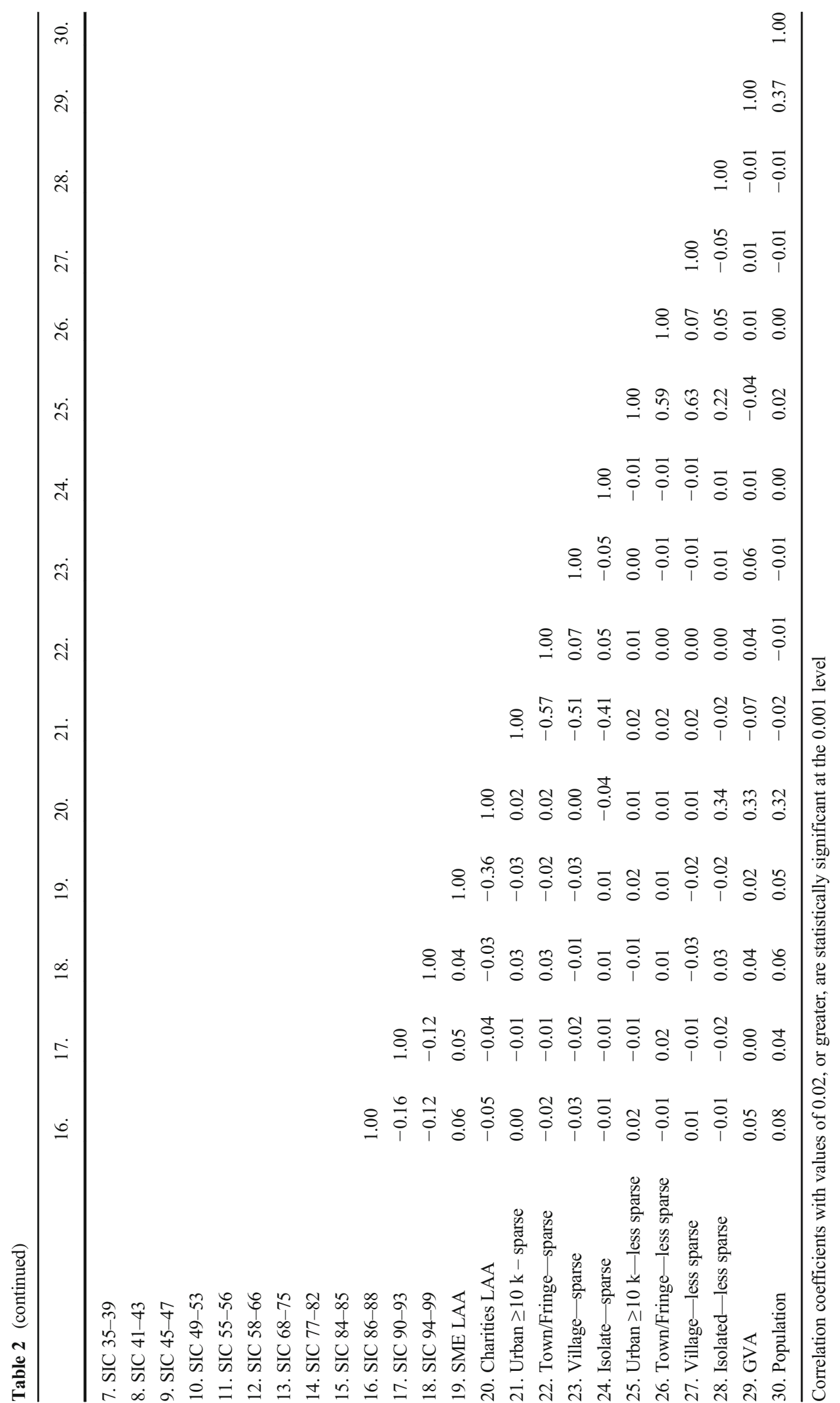




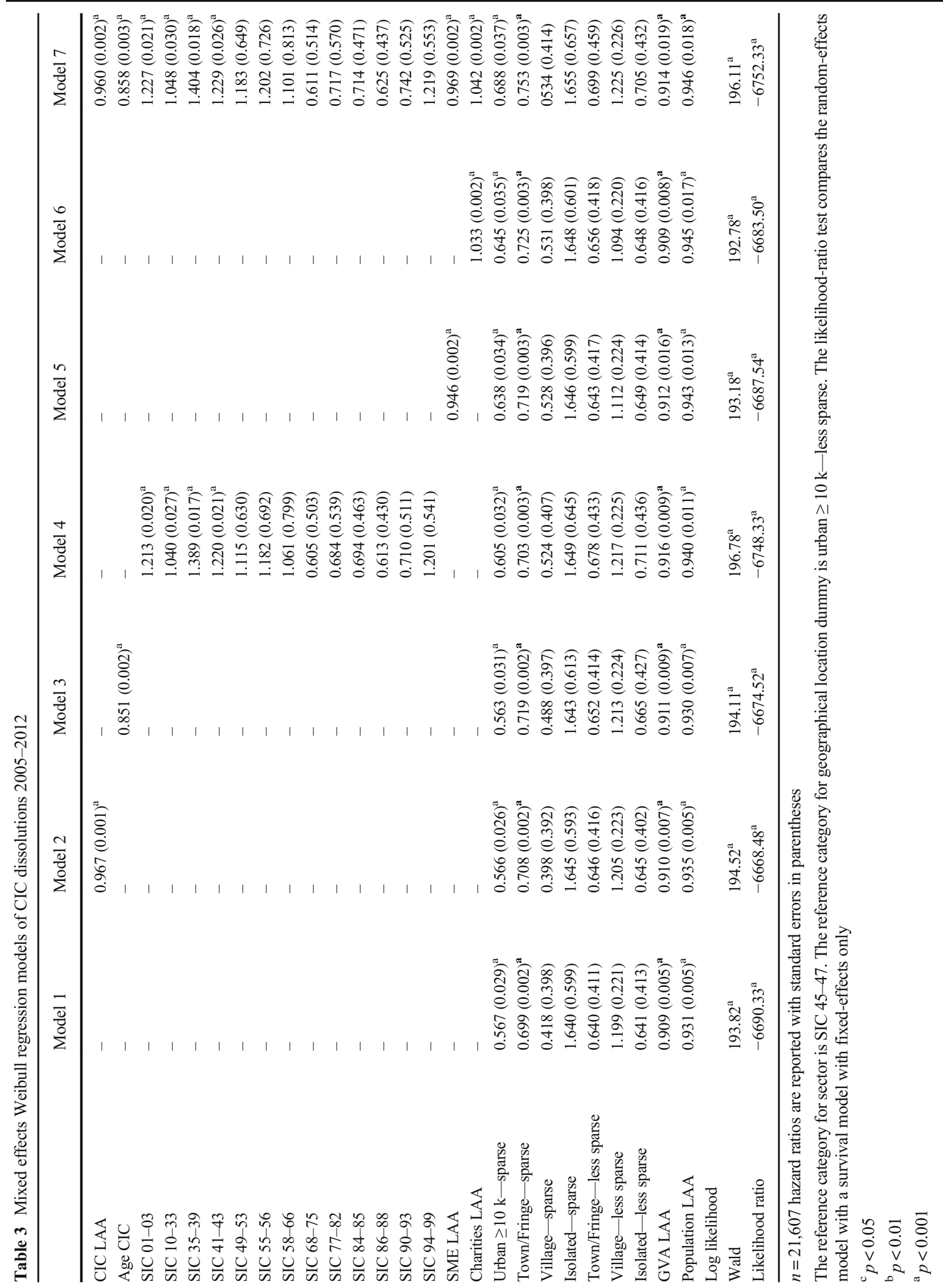


when compared to CICs located in urban $\geq 10 \mathrm{k}$, less sparse areas.

\subsection{Diagnostics}

The Weibull distribution is a continuous probability distribution (Weibull 1951; Stata 2019) that has been widely applied to look at product reliability, analyse life data, and model failure times across many disciplines including biology, economics, and engineering (Rinne 2008). The Weibull distribution is not universally applicable; for example, chemical reactions and corrosion failures are often modelled using a lognormal distribution. In Stata the LR test versus the Weibull model indicated that the Weibull model was appropriate (Stata 2019).

Assessing the goodness of fit with binary data and especially in a survival setting is challenging (Cox and Snell 1989; Blossfeld et al. 2012). We employed the D'Agostino and Nam (2004) test that is an extension of the Hosmer-Lemeshow goodness-of-fit test. Demler et al. (2015) provide a critique of the D'Agostino and Nam (2004) test. When we ran the ND test, the statistic was statistically significant at the 0.23 level, and thus it was not statistically significant at the $10 \%$ level or better and provides support for goodness of fit. An alternative approach is to model validation by using outside data, but this was not possible for our study. Instead, we split the data into two time periods and re-ran the models separately over the two time periods 2005-2008 and 2009-2012. While there were changes in hazard ratios, the variables which were statistically significant in our full model remained statistically significant in the models of the two time periods; and further, the variables which were not statistically significant in our fulltime period also continued to be not statistically significant in the models of the two time periods.

\section{Discussion and conclusion}

\subsection{Discussion}

The examination of the total population of CICs in the UK revealed that density dependence explains SE survival during population emergence. Our results follow the pattern that as SE founding rates increase, this encourages the founding of more SEs, and the greater the number of SEs in the population, the more likely SEs will survive. Despite the multitude of studies that have argued for the distinctiveness of SE, our finding, and contribution to population ecology theory, is that population ecology theory predictions relate to organizational form, irrespective of the nature of the organizational form.

When examining heterogeneity within the nascent SE population, we found that our results regarding the age of SEs support the liability of newness (Stinchcombe 1965) in that older SEs are more likely to survive than younger SEs. We attribute the higher likelihood of older SE survival to two explanations. First, after registration, a CIC has approximately 24 months before submission of the first set of audited accounts. During this start-up period, a CIC may survive on its initial stock of resources (Nucci 1999) and ride out peaks and troughs in income generation. However, failure to submit the audited accounts incurs from the CIC regulator a formal warning and notice of intention to deregister the CIC. The requirement to submit the first set of audited accounts will thus weed out the less commercially viable CICs. Second, older CICs are more proficient at accessing resources, acquiring skills and expertise, leveraging professional advice and trade associations, and constructing supportive networks. While older organizations may suffer liabilities of obsolescence (Barron et al. 1994), this effect was not found during SE population emergence.

We predicted that being able to access resources from a range of different sources and serve wider markets would mean that generalists were more likely to survive than specialist SEs. The results suggest that the expected impact on survival of strategic differences is ambiguous. With the exceptions of sectors such as agriculture, forestry and fishing, utilities, construction, and manufacturing, survival is significantly influenced by the specialist nature of sectors in which SEs operate. We label this effect the liability of specificity. Generalist SEs are more able to be flexible in the types of resources they access and markets they serve, and such flexibility spreads risk (Dobrev et al. 2001) and increases the likelihood of survival. For example, a CIC in the wholesale and retail sectors could spread risk by serving customers in a wider range of markets than, for example, a CIC in the utilities industry, such as a community-owned wind farm, because the specialist focus and asset specificity constrain flexibility. Further, the high capital costs of organizations in agriculture, forestry and fishing, 
utilities, construction, and manufacturing may also impact negatively on SE survival.

The analysis of nascent inter-population densities of SEs, SMEs, and charities finds that SE survival is statistically significantly related to the density of both populations; however, this finding has an important caveat. There is a strong degree of intertwining between the relationships that means the results need to be treated with caution. There is a positive inter-population relationship between SE survival and SMEs and a negative relationship between SEs and charities. We attribute the complementary inter-population relationship (Aldrich 1990; Audia et al. 2006) to the dual logic of SEs in which the impact of the commercial focus that they share with SMEs is attenuated by the simultaneous pursuit of social purpose, thereby preventing full and direct competition with commercial SMEs. We label this effect the hybrid-commercial benefit which, for SEs, means that they benefit from the contextual conditions that support commercial SMEs. The supportive institutional conditions might be, for example, a pool of skilled labour, transportation and communication infrastructure, supply networks, and technological support (Bielefeld and Murdoch 2004; Marquis et al. 2013). SEs gain from such contextual conditions without compromising their social mission or directly competing with commercial SMEs. For example, in health care services and hospitality industries, CICs and commercial providers employ staff with similar knowledge and skills but target different customer groups.

While SEs have a portfolio of income sources, few generate all their income from trading, and they will therefore be in direct competition with charities for grants, donations, and programme-related investment. Moreover, some charities also generate mission-related income. While social goal achievement potentially could be greater if SEs and charities cooperated with each other (Austin and Seitanidi 2012), SEs and charities may also be competing for the same resources and in the same markets. The competition between SEs and charities for resources and markets explains the negative impact on SE survival. For example, both SEs and charities would be eligible to bid for a contract to supply work integration services, but only one provider could secure the contract. The SE combination of commercial expertise and social mission suggests that they are more likely to secure the contract.

\subsection{Theoretical contributions}

The research offers several contributions to population ecology theory (Fiol and Romanelli 2012). First, we extend the empirical frontiers of population emergence by empirically investigating SEs. Although previous studies have examined commercial (Hannan et al. 1995; MacKay and Chia 2013; Swaminathan 2001; Wade 1996) and non-profit organizations (Baum and Oliver 1992; Gras and Mendoza-Abarca 2014; Hannan and Freeman 1987), SEs combine characteristics of both types of organizations. We predicted that as the population density of SEs increased, survival would also increase, and this pattern was found in UK SE population emergence.

Second, in a departure from previous studies, our research is not restricted to a single industry, for example, newspapers (Hannan and Carroll 1992), communications (Barnett and Amburgey 1990), and day care (Baum and Oliver 1992). By analysing the entire CIC population, we were able to isolate the effects of the liability of specificity on SE survival. While there are some environments in which specialists outperform generalists (Hannan and Freeman 1977), such as when the population density of generalists increases and creates more opportunities for specialists (Carroll 1985), this was not found during SE population emergence. Third, our results found a positive relationship between SE survival and the population densities of SEs and commercial organizations and a negative relationship between SEs and registered charities. We attributed this result to SE hybridity in that the conditions that foster founding and survival of SEs are shared with commercial SMEs. The hybrid-commercial benefit describes how SE survival benefits from sharing the business focus of commercial SMEs. The research serves as a first insight into how population ecology theory sheds light on contextual influences on SE survival during population emergence.

\subsection{Contributions to social entrepreneurship}

In a departure from the many qualitative studies of social entrepreneurship, we conducted a robust quantitative analysis of SE population emergence. The long heritage of organizational forms for commercial organizations and charities stands in contrast to the newness of the CIC form. The pursuit of commercial and social mission in one organizational form, however, creates 
several challenges. On the one hand, there is the profit maximizing characteristic of commercial organizations; on the other hand, there is the social and environmental mission to give time, money, care, and hope to individuals and communities. Prior social entrepreneurship research has acknowledged that SEs have prospered in some countries and not others and attributed differential performance to institutional differences (Cherrier et al. 2018; Kerlin 2017). By focusing on organizational form, our research finds that contextual conditions, specifically the population density of other SEs and commercial SMEs, also influences SE survival.

\subsection{Practical implications}

For practitioners and policy makers, our study offers three suggestions for strengthening the prospects of SE survival. First, at present the population density of SEs is increasing, and this benefits their survival. Policies to encourage the establishment of more SEs will help practitioners until the rate of dissolutions rises and indicates that environmental carrying capacity has been reached. However, as younger SEs are at higher risk of dissolution than older SEs, policies to assist the navigation of the risky earlier years would be beneficial. Second, the liability of specificity suggests that founders of SEs in specific industries need to be aware of, and prepare for, the negative influence of some industries on SE survival. Business support and advice could be tailored to raise awareness of the greater risk of dissolution inherent in some industries and from specialist strategies. Finally, the identification of the hybridcommercial benefit serves to encourage social entrepreneurs to interpret the density of commercial SMEs, and hence the vibrancy of commercial trading, as an indication of good survival prospects for SEs. At the same time, the impact of competition between SEs and charities implies that the density of charities would be disadvantageous to SE survival.

\subsection{Limitations and suggestions for future research}

Although the robustness of the analysis of the assembled data sets findings has several strengths, we note a number of research limitations. First, the operationalization of SE birth, which we defined as the date of incorporation as recorded on the CIC register, may in some cases supersede operational start-up (Amburgey and Rao 1996). Although our measure may not accurately reflect the start of commercial activity, the date of trading is not employed as an indicator of birth for commercial organizations nor charities, and hence our measure is in line with that of other organizational forms. Further, we elected to study population density, not size, because size may be less important for SE survival than institutional linkages (Baum and Oliver 1992). We therefore did not control for organization size, and the results do not capture age dependence effects (Barnett 1997; Barron et al. 1994; Freeman et al. 1983). Finally, population ecology theory tends to assume that organizational survival is favourable, yet dissolution need not necessarily be an undesirable outcome (Sorenson and Audia 2000). Indeed, dissolution may be an indication that the SE has succeeded in social mission achievement, such as correcting market failure or eliminating disadvantage, and that the CIC's assets have been acquired by another asset-locked organization.

We conclude by suggesting four themes to explore that follow from the study. First, although population ecology research advances knowledge about the determinants of organization founding and survival, the results in our study of SEs suggest that broader influences are also important. Further, population ecology theory implicitly assumes that each organization in a population contributes equally to competitive or legitimacy processes (Bogaert et al. 2016). Research to investigate the influence of a wider range of variables on SE density, location, and the anchoring effects of high-profile SEs would contribute to refining the boundary conditions during SE population emergence. Second, the 7year timeframe of our study explicitly captures the early ecology of SE when the establishment of the CIC was the first new legal form for nearly 100 years (Nicholls 2010). In 2012 a second new legal form was established, the Charitable Incorporated Organization (CIO), and further research that investigated the interplay between the CIC and the CIO would further extend knowledge on inter-population density. Third, the dissolution of SEs in our study is measured by delisting from the CIC register (16.6\% of the CICs were delisted). SE failure is a little understood phenomenon, and further research that investigates why CICs have been delisted would advance our understanding of the determinants of SE dissolution, replacement effects, and population decline. Finally, social entrepreneurs have a range of organizational forms to choose from, and quantitative investigations of SEs have been difficult for researchers when diverse measures and incomplete registers are 
maintained. We employed CIC data from the UK, and if the problems associated with compiling accurate population lists can be overcome, quantitative studies in other countries would facilitate international comparisons of the ecology of SEs. B Corporations, first certified in 2007, described as 'quite nascent' (Gehman et al. 2018 , p. 35) could offer further insights into SE population emergence. Additional research is needed as societal expectations concerning the role of SEs in serving the disadvantaged, excluded, and the poor continue to rise and the identification of the factors that determine their survival has the potential to influence both the supply of and demand for SEs.

Open Access This article is licensed under a Creative Commons Attribution 4.0 International License, which permits use, sharing, adaptation, distribution and reproduction in any medium or format, as long as you give appropriate credit to the original author(s) and the source, provide a link to the Creative Commons licence, and indicate if changes were made. The images or other third party material in this article are included in the article's Creative Commons licence, unless indicated otherwise in a credit line to the material. If material is not included in the article's Creative Commons licence and your intended use is not permitted by statutory regulation or exceeds the permitted use, you will need to obtain permission directly from the copyright holder. To view a copy of this licence, visit http://creativecommons.org/licenses/by/4.0/.

\section{References}

Abarca, K. M., \& Anokhin, S. (2012). Symbiosis or competition? The inter-population dynamics between social and commercial ventures. Frontiers of Entrepreneurship Research, 32(19), 1-5.

Aldrich, H. E. (1990). Using an ecological perspective to study organizational founding rates. Entrepreneurship: Theory and Practice, 14(3), 7-24. https://doi.org/10.1177 /104225879001400303.

Aldrich, H. E., \& Fiol, M. (1994). 'Only fools rush in?' The institutional context of industry creation. Academy of Management Review, 19(4), 102-120. https://doi. org/10.5465/amr.1994.9412190214.

Aldrich, H. E., \& Ruef, M. (2006). Organizing evolving. London, UK: Sage Publications. https://doi.org/10.4135 /9781446212509.

Aldrich, H. E., Zimmer, C. R., Staber, U. H., \& Beggs, J. J. (1994). Minimalism, mutualism, and maturity: The evolution of the American trade association population in the $20^{\text {th }}$ century. In J. Baum \& J. Singh (Eds.), Evolutionary dynamics of organizations (pp. 223-239). Oxford, UK: Oxford University Press. isbn:0-19-507736-9.

Amburgey, T. L., Kelly, D., \& Barnett, W. P. (1993). Resetting the clock: The dynamics of organizational change and failure.
Administrative Science Quarterly, 38, 51-73. https://doi. org/10.2307/2393254.

Amburgey, T. L., \& Rao, H. (1996). Organizational ecology: Past, present, and future directions. Academy of Management Journal, 39(5), 1265-1286. https://doi.org/10.2307/256999.

Amezcua, A. S., Grimes, M. G., Bradley, S. W., \& Wiklund, J. (2013). Organizational sponsorship and founding environments: A contingency view on the survival of businessincubated firms, 1994-2007. Academy of Management Journal, 56(6), 1628-1654. https://doi.org/10.5465 /amj.2011.0652.

Andersson, F. O., \& Ford, M. R. (2016). Social entrepreneurship through an organizational ecology lens: Examining the emergence and evolution of the voucher school population in Milwaukee. Voluntas, 27, 1760-1780. https://doi. org/10.1007/s11266-015-9576-0.

Audia, P. G., Freeman, J. H., \& Reynolds, P. D. (2006). Organizational foundings in community context: Instruments manufacturers and their interrelationship with other organizations. Administrative Science Quarterly, 51(3), 381-419. https://doi.org/10.2189/asqu.51.3.381.

Austin, J. E., \& Seitanidi, M. M. (2012). Collaborative value creation: A review of partnering between nonprofits and businesses. Part 2: Partnership processes and outcomes. Nonprofit and Voluntary Sector Quarterly, 41(5), 929-968. https://doi.org/10.1177/0899764012454685.

Austin, J., Stevenson, H., \& Wei-Skillern, J. (2006). Social and commercial entrepreneurship: Same, different or both? Entrepreneurship: Theory and Practice, 30(1), 1-22. https://doi.org/10.1111/j.1540-6520.2006.00107.x.

Austin, P. C. (2017). A tutorial on multilevel survival analysis: Methods, models and applications. International Statistical Review, 85(2), 185-203. https://doi.org/10.1111/insr.12214.

Bacq, S., \& Janssen, F. (2011). The multiple faces of social entrepreneurship: A review of definitional issues based on geographical and thematic criteria. Entrepreneurship and Regional Development, 23(5-6), 373-403. https://doi. org/10.1080/08985626.2011.577242.

Barnett, W. P. (1990). The organizational ecology of a technological system. Administrative Science Quarterly, 35(1), 31-60. https://doi.org/10.2307/2393550.

Barnett, W. P. (1997). The dynamics of competitive intensity. Administrative Science Quarterly, 42(1), 128-160. https://doi.org/10.2307/2393811.

Barnett, W.P., \& Amburgey, T.L. (1990). Do larger organizations generate stronger competition? In Organizational evolution: New directions, Singh J (Ed.). Sage: Newbury Park, CA, pp. 78-102. ISBN-10: 0803936583.

Barnett, W. P., \& Carroll, G. R. (1987). Competition and mutualism among early telephone companies. Administrative Science Quarterly, 32(3), 400-421. https://doi.org/10.2307 12392912.

Baron, J. N. (2004). Employing identities in organizational ecology. Industrial and Corporate Change, 13, 3-32. https://doi. org/10.1093/icc/13.1.3.

Barron, D. N. E., West, E., \& Hannan, M. T. (1994). A time to grow and a time to die: Growth and mortality of credit unions in New York City, 1914-1990. American Journal of Sociology, 100(2), 381-421. https://doi.org/10.1086/230541. 
Battilana, J., Lee, M., Walker, J., \& Dorsey, C. (2012). In search of the hybrid ideal. Stanford Social Innovation Review, 10(4), 51-55. https://doi.org/10.7916/D8WD497M.

Baum, J. A. C., \& Haveman, H. A. (1997). Love they neighbour? Differentiation and agglomeration in the Manhattan hotel industry, 1898-1990. Administrative Science Quarterly, 42(2), 304-338. https://doi.org/10.2307/2393922.

Baum, J. A. C., \& Oliver, C. (1992). Institutional embeddedness and the dynamics of organizational populations. American Sociological Review, 57(4), 540-559. https://doi.org/10.2307 1257003

Bielefeld, W., \& Murdoch, J. C. (2004). The locations of nonprofit organizations and their for-profit counterparts: An exploratory analysis. Nonprofit and Voluntary Sector Quarterly, 33(2), 221-246. https://doi.org/10.1177/0899764003260589.

Billis, D. (2010). Hybrid Organizations and the Third Sector. Palgrave Macmillan: London. ISBN-13: 978-0-230-23463-5.

Bird, M., \& Wennberg, K. (2014). Regional influences on the prevalence of family versus non-family start-ups. Journal of Business Venturing, 29(3), 421-436. https://doi.org/10.1016 /j.jbusvent.2013.06.004.

Blossfeld, H.-P., Golsch, K., \& Rohwer, G. (2012). Event history analysis with Stata. New York \& London: Psychology Press. https://doi.org/10.4324/9780203936559.

Bogaert, S., Boone, C., Negro, G., \& van Witteloostuijn, A. (2016). Organizational form emergence: A meta-analysis of the ecological theory of legitimation. Journal of Management, 42(5), 1344-1373. https://doi.org/10.1177 /0149206314527129.

Boone, C., \& Öscan, A. (2014). Why do cooperatives emerge in a world dominated by corporations? The diffusion of cooperatives in the U.S. bioethanol industry, 1978-2013. Academy of Management Journal, 57(4), 990-1012. https://doi. org/10.5465/amj.2012.0194.

Bosma, N., Stam, E., \& Schutjens, V. (2011). Creative destruction and regional productivity growth: Evidence from the Dutch manufacturing and services industries. Small Business Economics, 36, 401-418. https://doi.org/10.1007/s11187009-9257-8.

Bouchard, M. J., \& Rousselière, D. (2016). Do hybrid organizational forms of the social economy have a greater chance of surviving? An examination of the case of Montreal. Voluntas, 27, 1894-1922. https://doi.org/10.1007/s11266-015-9664-1.

Brandsen, T. W., van de Donk, W., \& Putters, K. (2005). Griffins or chameleons? Hybridity as a permanent and inevitable characteristic of the third sector. International Journal of Public Administration, 28(9-10), 1749-1765. https://doi. org/10.1081//PAD-200067320.

Brittain, J. (1994). Density-independent selection and community evolution. In J.A.C. Baum \& J.V. Singh (Eds.). Evolutionary Dynamics of Organizations, Oxford University Press: New York, NY, pp. 355-378. ISBN 0-19-507736-9.

Brittain, J.W., \& Freeman, J.H. (1980). Organizational proliferation and density dependent selection. In J. Kimberley \& R. Miles (Eds.). Organizational life cycles, Jossey Bass: San Francisco, pp. 291-338. ISBN-10: 0875894593.

Carroll, G. R. (1984). Organizational ecology. Annual Review of Sociology, 101(1), 71-93. https://doi.org/10.1146/annurev. so.10.080184.000443.

Carroll, G. R. (1985). Concentration and specialization: Dynamics of niche width in populations of organizations. American
Journal of Sociology, 90(6), 1262-1283. https://doi. org/10.1086/228210.

Carroll, G. R., Delacroix, J., \& Goodstein, J. (1988). The political environments of organizations: An ecological view. Research in Organizational Behavior, 10, 359-392.

Chang, E. P. C., Chrisman, J. J., \& Kellermans, F. W. (2011). The relationship between prior and subsequent new venture creation in the United States: A county level analysis. Journal of Business Venturing, 26(2), 200-211. https://doi.org/10.1016 /j.jbusvent.2009.05.001.

Cherrier, H., Goswani, P., \& Ray, S. (2018). Social entrepreneurship: Creating value in the context of institutional complexity. Journal of Business Research, 86, 245-258. https://doi. org/10.1016/j.jbusres.2017.10.056.

Cooney, K. (2006). The institutional and technical structuring of non-profit ventures: Case study of a U.S. hybrid organization caught between two fields. Voluntas, 17(2), 137-155. https://doi.org/10.1007/s11266-006-9010-8.

Cooney, K. (2011). An exploratory study of social purpose business models in the United States. Nonprofit and Voluntary Sector Quarterly, 40(1), 185-196. https://doi.org/10.1177 /0899764009351591.

Cox, C.R., \& Snell, E.J. (1989). Analysis of binary data. Second Edition. Chapman \& Hall/CRC: Boca Raton, FL, USA. ISBN: 9780412306204.

Dacin, P. A., Dacin, M. T., \& Matear, M. (2010). Social entrepreneurship: Why we don't need a new theory and how we move forward from here. Academy of Management Perspectives, 24(3), 37-57. https://doi.org/10.5465 /amp.24.3.37.

Dacin, M. T., Dacin, P. A., \& Tracey, P. (2011). Social entrepreneurship: A critique and future directions. Organization Science, 22(5), 1203-1213. https://doi.org/10.2307 /41303113.

D'Agostino, R. B., \& Nam, B.-H. (2004). Evaluation of the performance of survival analysis models: Discrimination and calibration measures. Handbook of Statistics, 23, 1-25. https://doi.org/10.1016/S0169-7161(03)23001-7.

Davidsson, P., \& Wiklund, J. (2001). Levels of analysis in entrepreneurship research: Current research practice and suggestions for the future. Entrepreneurship: Theory and Practice, 25(4), 81-100. https://doi.org/10.1177 $/ 104225870102500406$.

DBEIS (2016). Office of the Regulator of Community Interest Companies. Information and Guidance Notes. Department of Business, Energy \& Industrial Strategy. London, UK.

Dees, J. G., \& Anderson, B. B. (2003). For profit social ventures. International Journal of Entrepreneurship Education, 2(1), $1-26$.

Delacroix, J., \& Carroll, G. R. (1983). Organizational foundings: An ecological study of the newspaper industries of Argentina and Ireland. Administrative Science Quarterly, 28(2), 274291. https://doi.org/10.2307/2392621.

Demler, O. V., Paynter, N. P., \& Cook, N. R. (2015). Tests of calibration and goodness-of-fit in the survival setting. Statistics in Medicine, 34, 1659-1680. https://doi. org/10.1002/sim.6428.

Di Domenico, M., Haugh, H., \& Tracey, P. (2010). Social bricolage: Theorizing social value creation in social enterprises. Entrepreneurship: Theory and Practice, 34(4), 681-703. https://doi.org/10.1111/j.1540-6520.2010.00370.x. 
Dobrev, S. D., Kim, T.-Y., \& Hannan, M. T. (2001). Dynamics of niche width and resource partitioning. American Journal of Sociology, 106, 1299-1337. https://doi.org/10.1086/320821.

DTI. (2002). Social Enterprise strategy: A strategy for success. London, UK: Department for Trade and Industry.

Estrin, S., Mickiewicz, T., \& Stephan, U. (2013). Entrepreneurship, social capital, and institutions: Social and commercial entrepreneurship across nations. Entrepreneurship: Theory and Practice, 37(3), 479-504. https://doi.org/10.1111/etap.12019.

Fiol, C. M., \& Romanelli, E. (2012). Before identity: The emergence of new organizational forms. Organization Science, 23(3), 597-611. https://doi.org/10.1287/orsc.1110.0666.

Freeman, J., \& Audia, P. G. (2006). Community ecology and the sociology of organizations. Annual Review of Sociology, 32, 145-169. https://doi.org/10.1146/annurev. soc.32.061604.123135.

Freeman, J. M., Carroll, G. R., \& Hannan, M. T. (1983). The liability of newness: Age dependence in organizational death rates. American Sociology Review, 48(5), 692-710.

Gehman, T., Grimes, M. G., \& Cao, K. (2018). Commentary. Why we care about certified B corporations: From valuing growth to certifying values. Academy of Management Discoveries, 5(1), 97-101. https://doi.org/10.5465/amd.2018.0074.

Geoconvert (2004). UK data service census report. Available at: http://geoconvert.mimas.ac.uk/

Goldstein, H. (2011). Multilevel Statistical Models. John Wiley and Sons Ltd: West Sussex. isbn:9781119956822.

Gras, D., \& Mendoza-Abarca, K. L. (2014). Risky business? The survival implication of exploiting commercial opportunities by nonprofits. Journal of Business Venturing, 29(3), 392404. https://doi.org/10.1016/j.jbusvent.2013.05.003.

Hager, M. A., Galaskiewicz, J., \& Larson, J. A. (2004). Structural embeddedness and the liability of newness among nonprofit organizations. Public Management Review, 6(2), 159-188. https://doi.org/10.1080/1471903042000189083.

Halliday, T. C., Powell, M. J., \& Granfors, M. W. (1987). Minimalist organizations: Vital events in state bar associations, 1870-1930. American Sociology Review, 52(4), 456471.

Hannan, M.T., \& Carroll, G. (1992). Dynamics of organizational populations, density, legitimation and competition. Oxford University Press: New York, NY. ISBN-10: 0195071913.

Hannan, M. T., Carroll, G. R., Dundon, E. A., \& Torres, J. C. (1995). Organizational evolution in a multinational context: Entries of automotive manufacturers in Belgium, Britain, France, Germany, and Italy. American Sociology Review, 60(4), 509-528. 10.23072096291.

Hannan, M. T., \& Freeman, J. M. (1977). The population ecology of organizations. American Journal of Sociology, 82(5), 929964. https://doi.org/10.1086/226424.

Hannan, M. T., \& Freeman, J. M. (1987). The ecology of organizational founding: American labor unions, 1836-1985. American Journal of Sociology, 92(4), 910-943. https://doi. org/10.1086/228587.

Hannan, M. T., \& Freeman, J. M. (1989). Organizational ecology. Cambridge, MA: Harvard University Press. isbn: 9780674643499.

Henderson, A. D. (1999). Firm strategy and age dependence: A contingent view of the liability of newness, adolescence and obsolescence. Administrative Science Quarterly, 44, 281314. https://doi.org/10.2307/2666997.

Ingram, P., \& Simons, T. (2000). State formation, ideological competition, and the ecology of Israeli workers' cooperatives, 1920-1992. Administrative Science Quarterly, 45(1), 25-53. https://doi.org/10.2307/2666978.

Kachlami, H. (2017). Regional dynamism between social and commercial ventures. An empirical study based on Swedish data. International Journal of Social Economics, 44(9), 1122-1138. https://doi.org/10.1108/IJSE-11-2015-0293.

Katz, R. A., \& Page, A. (2010). Symposium. Corporate creativity. The Vermont L3C and other developments in social entrepreneurship. The role of social enterprise. Vermont Law Review, 35, 1-9.

Kerlin, J. A. (2017). Shaping social enterprise: Understanding institutional context and influence. Bingley, UK: Emerald. isbn:978-1-78714-251-0.

Kickul, J., Terjesen, S., \& Justo, R. (2013). Small business economics special issue introduction. Small Business Economics, 40(3), 687-691. https://doi.org/10.1007 /s11187-011-9397-5.

King, B. G., Clemens, E. S., \& Fry, M. (2011). Identity realization and organizational forms: Differentiation and consolidation of identities among Arizona's charter schools. Organization Science, 22(3), 554-572. https://doi.org/10.1287 /orsc. 1100.0548 .

Lambkin, M., \& Day, G. S. (1989). Evolutionary processes in competitive markets: Beyond the product life cycle. Journal of Marketing, 53(3), 4-20. https://doi.org/10.2307/1251339.

Lepoutre, J., Justo, R., Terjesen, S., \& Bosma, N. (2013). Designing a global standard methodology for measuring social entrepreneurship activity: The global entrepreneurship monitor social entrepreneurship study. Small Business Economics, 40(3), 693-714. https://doi.org/10.1007 /s11187-011-9398-4.

Liu, M., \& van Witteloostuijn, A. (2020). Emergence of entrepreneurial populations: A feature dimensionality approach. Small Business Economics, 54, 971-989. https://doi. org/10.1007/s11187-018-0126-1.

Lomi, A. (1995). The population ecology of organizational founding: Location dependence and unobserved heterogeneity. Administrative Science Quarterly, 40(1), 111-144. https://doi.org/10.2307/2393702.

Lomi, A., Larsen, E. R., \& Wezel, F. C. (2010). Getting there: Exploring the role of expectations and preproduction delays in processes of organizational founding. Organization Science, 21(1), 132-149. https://doi.org/10.1287 /orsc. 1090.0437.

MacKay, R. B., \& Chia, R. (2013). Choice, change, and the unintended consequences in strategic change: A process understanding of the rise and fall of North Co Automotive. Academy of Management Journal, 56(1), 208-230. https://doi.org/10.5465/amj.2010.0734.

Marquis, C., Davis, G. F., \& Glynn, M. A. (2013). Golfing alone? Corporations, elites, and nonprofit growth in 100 American communities. Organization Science, 24(1), 39-57. https://doi.org/10.1287/orsc.1110.0717.

Mendoza-Abarca, K. I., Anokhin, S., \& Zamudio, C. (2015). Uncovering the influence of social venture creation on commercial venture creation: A population ecology perspective. 
Journal of Business Venturing, 30(6), 793-807. https://doi. org/10.1016/j.jbusvent.2015.04.003.

Minkoff, D. (2002). The emergence of hybrid organizational forms: Combining identity-based service provision with political action. Nonprofit and Voluntary Sector Quarterly, 31(3), 377-401. https://doi.org/10.1177 /0899764002313004.

Mort, G. S., Weerawardena, J., \& Carnegie, K. (2003). Social entrepreneurship: Towards conceptualisation. International Journal of Nonprofit and Voluntary Sector Marketing, 8(1), 76-88. https://doi.org/10.1002/nvsm.202.

NCVO. (2004-2012). Civil society almanac. National Council of Voluntary Organisations: London, UK.

Nicholls, A. (2010). The legitimacy of social entrepreneurship: Reflexive isomorphism in a pre-paradigmatic field. Entrepreneurship: Theory and Practice, 34(4), 611-633. https://doi.org/10.1111/j.1540-6520.2010.00397.x.

Nucci, A. R. (1999). The demography of business closings. Small Business Economics, 12, 25-39. https://doi.org/10.1023 /A:1008036821487.

Núñez-Nickel, M., \& Moyano-Fuentes, J. (2006). New size measurements in population ecology. Small Business Economics, 26, 61-81. https://doi.org/10.1007/s11187-004-6484-x.

OECD. (2014). OECD SME and entrepreneurship outlook. Paris: OECD.

ONS. (2004-2012). Annual population survey. Office of National Statistics: London, UK.

OXRIM. (2014). Retail and wholesale: Key sectors for the European economy. Institute of Retail Management: Said Business School, University of Oxford.

Persson, H. (2004). The survival and growth of new establishments in Sweden, 1987-1995. Small Business Economics, 23, 423-440. https://doi.org/10.1007/s11187-004-3992-7.

Rabe-Hesketh, S., \& Skrondal, A. (2012). Multilevel and longitudinal modeling using Stata, volume 2: Categorical responses, counts, and survival (Vol. 2: StataCorp LP). TX: College Station.

Ranger-Moore, J. (1997). Bigger may be better but is older wiser? Organizational age and size in the New York Life Insurance industry. American Sociological Review, 62, 903-920. https://doi.org/10.2307/2657346.

Raven, R. (2007). Niche accumulation and hybridisation strategies in transition policies towards a sustainable energy system: An assessment of differences and pitfalls. Entergy Policy, 35, 2390-2400. https://doi.org/10.1016/j.enpol.2006.09.003.

Rinne, H. (2008). The Weibull Distribution: A Handbook. CRC Press: Boca Raton, FL, USA. ISBN: 13: 978-1-4200-8743-7.

Romanelli, E. (1989). Organization birth and population variety: A community perspective on origins. In B. M. Staw \& L. L. Cummings (Eds.). Research in Organizational Behaviour, pp. 211-246. ISBN-10: 0892329211.

Roundy, P. T. (2017). Social entrepreneurship and entrepreneurial ecosystems. Complementary or disjoint phenomena? International Journal of Social Economics, 44(9), 12521267. https://doi.org/10.1108/IJSE-02-2016-0045.

Ruef, M. (2000). The emergence of organizational forms: A community ecology approach. American Journal of Sociology, 106(3), 658-714. https://doi.org/10.1086/318963.

Ruef, M., \& Patterson, K. (2009). Credit and classification: The impact of industry boundaries in nineteenth century America.
Administrative Science Quarterly, 54(3), 486-520. https://doi.org/10.2189/asqu.2009.54.3.486.

Salamon, L. M. (1999). America's non-profit sector. New York: The Foundation Centre.

Simons, T., \& Ingram, P. (2003). Enemies of the state: The interdependence of institutional forms and the ecology of the Kibbutz, 1910-1997. Administrative Science Quarterly, 48(4), 592-621. https://doi.org/10.2307/3556638.

Singer, J. D., \& Willett, J. B. (2003). Applied longitudinal data analysis. New York, NY: Oxford University Press. isbn:019-515296-4.

Smiddy, L. O. (2010). Symposium. Corporate creativity. The Vermont L3C and other developments in social entrepreneurship. Introduction. Vermont Law Review, 35, 1-9.

Social Enterprise, U. K. (2017). 2017. Social Enterprise UK London: The Future of Business. The State of Social Enterprise UK.

Sorenson, O., \& Audia, P. G. (2000). The social structure of entrepreneurial activity: Geographic concentration of footwear production in the United States, 1940-1989. American Journal of Sociology, 106(2), 424-462. https://doi. org/10.1086/316962.

Staber, U. H. (1989). Organizational foundings in the cooperative sector of Atlantic Canada: An ecological perspective. Organization Studies, 10(3), 381-403. https://doi. org/10.1177/017084068901000305.

Stata. (2019). Stata multilevel mixed-effects reference manual release 16. College Station, Texas: Stata Press.

StataCorp. (2017a). Stata multilevel mixed-effects reference manual release 15. TX: StataCorp LP. College Station.

StataCorp (2017b). Stata: Release 15. Statistical Software. StataCorp LP, College Station: TX.

Stinchcombe, A. (1965). Social structure and organizations. In J. G. March (Ed.) Handbook of Organizations. Rand McNally: Chicago, pp. 142-193. ISBN: 978-0-415-82039-4 (volume 20).

Suchman, M. C. (1995). Managing legitimacy: Strategic and institutional approaches. Academy of Management Review, 20(3), 571-610. https://doi.org/10.2307/258788.

Swaminathan, A. (2001). Resource partitioning and the evolution of specialist organizations: The role of location and identity in the U.S. wine industry. Academy of Management Journal, 44(6), 1169-1185. https://doi.org/10.2307/3069395.

Teasdale, S. (2010). How can social enterprise address disadvantage? Evidence from an inner-city community. Journal of Nonprofit \& Public Sector Marketing, 22(2), 89-107. https://doi.org/10.1080/10495141003601278.

Tracey, P., Phillips, N., \& Jarvis, O. (2011). Bridging institutional entrepreneurship and the creation of new organizational forms: A multilevel model. Organization Science, 22(1), 60-80. https://doi.org/10.1287/orsc.1090.0522.

Tucker, D. J., Singh, J. V., \& Meinhard, A. G. (1990). Organizational form, population dynamics, and institutional changes: The founding patterns of voluntary organizations. Academy of Management Journal, 33(1), 151-178. https://doi.org/10.5465/256356.

Wade, J. (1996). A community-level analysis of sources and rates of technological variation in the microprocessor market. Academy of Management Journal, 39(5), 1218-1244. https://doi.org/10.2307/256997. 
Watson, G. F., Worm, S., Palmatier, R. W., \& Ganesan, S. (2015). The evolution of marketing channels: Trends and research directions. Journal of Retailing, 91(4), 546-568.

Weibull, W. (1951). A statistical distribution function of wide applicability. Journal of Applied Mechanics, 18, 292-297. https://doi.org/10.4236/jamp.2019.712209.

Williamson, O. E. (1995). The economic institutions of capitalism. New York: Free Press.

Wry, T., Lounsbury, M., \& Jennings, P. D. (2014). Hybrid vigor: Securing venture capital by spanning categories in nanotechnology. Academy of Management Journal, 57(5), 13091333. https://doi.org/10.5465/amj.2011.0588.

Zahra, S. A., Gedajlovic, E., Neubaum, D. O., \& Shulman, J. M. (2009). A typology of social entrepreneurs: Motives, search processes and ethical challenges. Journal of Business Venturing, 24(5), 519-532. https://doi.org/10.1016/j. jbusvent.2008.04.007.
Zahra, S. A., Rawhouser, H. N., Bhawe, N., Neubaum, D. O., \& Hayton, J. C. (2008). Globalization of social entrepreneurship opportunities. Strategic Entrepreneurship Journal, 2(2), 117-131. https://doi.org/10.1002/sej.43.

Zahra, S. A., \& Wright, M. (2011). Entrepreneurship's next act. Academy of Management Perspectives, 25(4), 67-83. https://doi.org/10.5465/amp.2010.0149.

Zuckerman, E. W. (1999). The categorical imperative: Securities analysts and the illegitimacy discount. American Journal of Sociology, 104(5), 1398-1438. https://doi.org/10.1086 /210178.

Publisher's note Springer Nature remains neutral with regard to jurisdictional claims in published maps and institutional affiliations. 